Bangladesh J. Plant Taxon. 20(2): 267-279, 2013 (December)

(C) 2013 Bangladesh Association of Plant Taxonomists

\title{
PLANT TAXONOMIC RESEARCH IN BANGLADESH (1972-2012): A CRITICAL REVIEW
}

\author{
Haseeb MD. IRFANULlah \\ Practical Action, Bangladesh Country Office, House 12/B, Road 4, \\ Dhanmondi R/A, Dhaka 1205, Bangladesh
}

Keywords: Taxonomists; Taxonomy; Perception; Sustainable development, Bangladesh.

\begin{abstract}
Amid serious concerns over declining taxonomic research world-wide, Bangladesh showed positive trends over 1972-2002. Some important developments in the global arena over the last decade give a mixed view on the growth of taxonomic research. This demands revisiting Bangladesh's plant taxonomic research to identify major factors guiding its courses. Taxonomic papers published in three Bangladeshi journals and the Flora of Bangladesh (1972-2012) were analyzed using a scoring system. The present study reveals a four-fold increase in annual average of integrated taxonomic studies (those use knowledge of other branches of biology) over the last decade compared with the preceding decade. Conventional, inventory type taxonomic studies, on the other hand, has reduced by $15 \%$. Studies on algae showed $42 \%$ increase in annual average, while studies on angiosperms remained unchanged. Although unpublished researches like Master's theses increased significantly in recent years, the number of published work has decreased. The possible reasons for such decline are no net increase in plant taxonomists over the last decade, taxonomists struggling to transform researches into publishable manuscripts, and enhanced reputation of Bangladeshi journals increasing the proportion of foreign papers (a situation termed as 'reputational backlash'). The paper envisages that classical taxonomic studies will dominate in Bangladesh in the coming decades given the enormous exploratory task awaiting the taxonomists. It concludes that to put taxonomy in the sustainable development discourse, taxonomists must change their perception towards their role in the society and proactively share their work with wider audience.
\end{abstract}

\section{Introduction}

In their recent review, Costello et al. (2013a) declared - "Taxonomists are not in danger of extinction". In fact taxonomists' number has increased over the past couple of decades. Increased rate of publication over the last decade also shows taxonomic effort has never been greater. Costello et al. (l.c.) are not alone; a few other recent studies have also shared similar positive trends in taxonomic research in recent times (e.g. Joppa et al., 2011a; De Clerck et al., 2013; Tancoigne and Dubois, 2013). These analyses overturn the concerns expressed over declining 'taxonomy' and 'taxonomists' (Lee, 2000; Godfray, 2002; Irfanullah, 2006). In the wake of these worrying scenarios, the flow of recommendations to save taxonomy and the taxonomists has never dried out. Offers on the table are diverse - reemphasizing taxonomy course at the universities, training for more professional taxonomists, capitalizing on the strength of amateurs and parataxonomists, shifting in the perception of funding system to invest more in taxonomy, and making alliance with other branches of biology (Bramley, 1994; Disney, 1998; Lee, 2000; Boero, 2001; Godfray, 2002; Irfanullah 2003, 2006; Jones, 2008; Ebach et al., 2011; Pearson et al., 2011; Costello et al. 2013a; Sluys, 2013).

In recent years, these propositions are becoming seemingly radical, aiming at making taxonomy a fast, exciting discipline. Figueiredo et al. (2010) advocated for the removal of the mandatory requirement of Latin diagnosis while describing a new plant taxon from the 
International Code of Botanical Nomenclature (ICBN) - branding it an "unnecessary impediment". It has also been suggested that, while describing a new species, the peer-review process could be bypassed to speed up information availability (Wheeler et al., 2012). The fantastic developments in information and communication technology, access to information on the World Wide Web and social networking have instigated new ways of thinking. To ease the identification of species, use of automated system (MacLeod et al., 2010), online system (McDade et al., 2011), social networking (Silvertown, 2010) and semantically (computer programming language) based digital systems (Deans et al., 2011) have been proposed for consideration. Revolutionary proposals also include a model where a species' information would be available in web-based repositories and content-management systems before it is formally named as a new species (Maddison et al., 2012).

In addition to changing rules or capitalizing on recent technological advancements, wider issues, like taxonomy as a profession, have also made the list of taxonomy-saving propositions. Taxonomy journals, for example, receive relatively lower Impact Factors, which have obvious career implications (Lee, 2000; Valdecasas et al., 2000; Ebach et al., 2011; Wägele et al., 2011). To increase the impact of taxonomy papers, it was proposed that whenever a species name is used, the author(s) of the species should be included and the original literature source should be cited (Werner, 2006; Wägele et al., 2011). In addition to increasing the citation of a taxonomic work to a greater extent, this system would duly recognize the contribution of that piece to science. Change in our current perception and attitude towards taxonomy profession has also been proposed. To improve the academic assessment system of systematic works, unconventional systems, like online voting by the peers on a scientific contribution, have been proposed (McDade et al., 2011).

Taxonomy has, however, always been stringent when it comes to changing established rules and norms. Therefore, not many of the above propositions have been widely accepted by the peers or subsequently by the ICBN. Nevertheless, the XVIII International Botanical Congress, held in Melbourne in July 2011, endorsed some end-of-an-era decisions (Knapp et al., 2011). From the first day of 2012, Latin description or diagnosis required for publishing the name of a new taxon was changed to a requirement for Latin or English description or diagnosis. From the same day, ICBN started accepting electronic publications in Portable Document Format (PDF) with International Standard Serial Numbers (ISSNs) or International Standard Book Numbers (ISBNs). But these journeys towards changes have been slow. It took almost two decades, for example, to accept electronic publications since the formation of the first Special Committee for Electronic Publication in 1993 at the Tokyo Congress (Knapp et al., 2006). Therefore, the apparently drastic propositions mentioned above may take some time to become widely accepted. Nevertheless, concerns over declining professional taxonomy are far from over (Pearson et al., 2011; de Carvalho et al., 2013; Sluys, 2013).

The developments and mixed trends of taxonomic research drawn above tell us what are going on at a global scale. These are often based upon analyses of enormous datasets. But, can information from relatively smaller scale, say a country, help us to understand the dynamics of taxonomic research better? Can such analysis capture something else missed in the bigger picture?

In 2003, a review of plant taxonomic research in Bangladesh revealed some positive trends during 1972-2002 (Irfanullah, 2003). I, therefore, take plant taxonomy of Bangladesh as a case to revisit and answer above questions. Bangladesh is a useful case to explore because since 2003 several noteworthy developments took place here directly linked with plant taxonomy. First, 28 volumes of Encyclopedia of Flora and Fauna of Bangladesh (henceforth, the Encyclopedia) were published during 2007-2009 under a big project of the Asiatic Society of Bangladesh. Almost all practicing plant taxonomists of the country were involved in this project as editors, contributors or 
researchers to produce 11 of those volumes (Volumes 2-12). These are cyanobacteria, bacteria and fungi (Volume 2) (Siddiqui et al., 2007a); algae (Volumes 3 \& 4) (Ahmed et al., 2007, 2009a); bryophytes, pteridophytes and gymnosperms (Volume 5) (Siddiqui et al., 2007b); and angiosperms (Volumes 6-12) (Siddiqui et al., 2007c; Ahmed et al., 2008a, b; Ahmed et al., 2009be). These have recorded full descriptions and images of all plant species discovered from Bangladesh territory. This long anticipated venture has given Bangladeshi taxonomists the opportunity to position themselves in national research and development arena.

Second, Bangladesh Journal of Plant Taxonomy (BJPT) has been published by Bangladesh Association of Plant Taxonomists since 1994. It is the only peer-reviewed, indexed journal from Bangladesh devoted to plant taxonomy and conservation. In 2007, BJPT started to be indexed by the Institute of Scientific Information (ISI). Until 2012, it had been indexed by many of the major indexing agencies. The journal is being published on-line (http://www.banglajol.info/index. php/BJPT) since 2008 along with the printed version. In June 2010, it received its first ISI Impact Factor. These developments enhanced the visibility and acceptability of this Bangladesh-origin journal, which was less known in the first 12 years of its existence. It is now attracting good number of taxonomists around the globe. In 2006, no foreign manuscript was submitted to BJPT. In 2007, out of 29 submitted manuscripts 10 were foreign (present author's record). In 2012, 122 manuscripts were submitted to BJPT of which 107 were by foreign authors (Md. Oliur Rahman, personal communication). One volume of BJPT consisting of just above 200 pages is published each year in two issues. Bangladesh Journal of Botany, published since 1972, is another ISIindexed plant sciences journal attracting foreign taxonomy papers over the last decade or so.

The third development is related to the education and research environment of Bangladesh. Tremendous development of information and communication technology has now given extensive, quality connectivity through internet technology. Access to world journals by the universities and research institutions are much easier now under different global 'access to information' projects. Both these have changed the face of education and research in Bangladesh over the last decade.

Against this backdrop, the present study first looks into the trends of plant taxonomic research in Bangladesh during 1972-2012. Based upon the findings, the study further explores i) what important factors are guiding plant taxonomic research in Bangladesh; ii) where the current trends are likely to go; and iii) what key issues need to be focused on by the plant taxonomists, especially after the era of Millennium Development Goals (MDGs) ends in 2015.

\section{Methodology}

To reveal the trends of plant taxonomic research in Bangladesh, both published and unpublished research works were considered. To qualify as a study of Bangladesh, the study material(s) (plant or place) must be from Bangladesh and should be carried out by one or more Bangladeshi scientists inside or outside Bangladesh. Details of the methodology are given below.

\section{Published research}

For published works, the methodology of Irfanullah (2003) was followed. Taxonomic papers published in three journals during the period of 1972-2012 were considered, with special focus on 2003-2012. These journals are Bangladesh Journal of Botany (BJB, published by Bangladesh Botanical Society since 1972), Journal of the Asiatic Society of Bangladesh, Science (JASBS, published by the Asiatic Society of Bangladesh since 1975) and Bangladesh Journal of Plant Taxonomy (BJPT). BJPT is an exclusively plant taxonomy journal, BJB is a plant sciences journal publishing taxonomy papers, while JASBS is used to be an important science journal for plant taxonomy, especially prior to BJPT. In addition, volumes of Flora of Bangladesh published by 
Bangladesh National Herbarium were included as revisions of angiosperm families (see below). Data on foreign papers published in Bangladeshi journals (2003-2012) were also analyzed to understand wider issues associated with taxonomic research. In the present study, unpublished raw data of Irfanullah (2003) were used for some analyses.

Categories: All taxonomic papers recorded were categorized under two separate schemes. In the first scheme, all papers were classified into two broad categories based upon the nature of the studies.

1. Inventory studies: The common feature of these studies is conventional morphological taxonomic approaches (include both morphology and anatomy) were taken to conduct them. This category includes papers on floristic studies (including checklists); new records for Bangladesh (or other countries); revisions of taxonomic groups; nomenclature (e.g. new to science and new combinations); micormorphology (using light or electron microscopes); and ethnobotany. The present analysis is different from Irfanullah (2003) as the latter considered floristic studies and checklists separately.

2. Integrated studies: In these studies knowledge of different branches of biology other than morphology and anatomy were used to elucidate taxonomic problems or to facilitate taxonomic understanding, or showed significant dependency on taxonomy to improve understanding of those branches. These branches are, for example chemistry, cytogenetics (including cytology), ecology (including limnology), and reproductive biology (including a very few papers on vegetative biology and seedling growth). Numerical taxonomy was also included in this category. The present category is different from Irfanullah (2003) because of extending the definition of cytogenetics and reproductive biology papers.

Table 1. Annual mean scores ( \pm standard error) of different types of taxonomic studies and plant groups published in three journals (Bangladesh Journal of Botany, Journal of the Asiatic Society of Bangladesh, Science, and Bangladesh Journal of Plant Taxonomy) in two periods. Definitions and comments on different study types are given in the methodology section. ${ }^{* *}$, value in this column is different from the counterpart at $p<0.01$. Data sources: 1994-2002, based on the raw data of Irfanullah (2003); 2003-2012, collected for the present study.

\begin{tabular}{lcc}
\hline Study types and plant groups & \multicolumn{2}{c}{ Study periods } \\
\hline Study types & $1994-2002$ & $2003-2012$ \\
Inventory studies & $47 \pm 4.5$ & $40 \pm 3.4$ \\
Integrated studies & $2.3 \pm 0.7$ & $10 \pm 2.3^{* *}$ \\
\hline Plant groups & & \\
Algae & $12 \pm 2.2$ & $17 \pm 2.1$ \\
Bryophytes & $4.9 \pm 1.7$ & $4.4 \pm 1.3$ \\
Pteridophytes & $3.6 \pm 0.8$ & $1.6 \pm 0.6$ \\
Gymnosperms & $0.1 \pm 0.1$ & 0 \\
Angiosperms & $27 \pm 3.9$ & $27 \pm 3.2$ \\
Mixed group & $1.7 \pm 0.73$ & - \\
\hline
\end{tabular}

The second scheme is based upon broad plant groups that a paper deals with. These groups are angiosperms, gymnosperms, pteridophytes (fern and fern-allies), bryophytes (mosses and liverworts) and algae (covering freshwater, brackishwater and marine taxa, including cyanobacteria or blue-green algae) (Table 1). Irfanullah (2003) considered 'mixed studies' as a separate group, where papers dealing with more than one plant group were placed. In 2003-2012, 
only a few papers, highly dominated by angiosperms, also had information on other plant groups. These were considered as angiosperm papers.

Scoring system: The scoring system of Irfanullah (2003) was followed - a full paper scored 3 (including each volume of Flora of Bangladesh), while a short communication scored 1. When a paper fell into more than one category, possible total score was distributed among the categories. Total score of a category in a given year was then used for statistical analyses. Of all the papers considered for this study, BJPT accounted for $59 \%$ of the score, BJB $32 \%$, JASBS $5 \%$ and the Flora of Bangladesh 4\%. Non-parametric Mann-Whitney U-tests (Social Science Statistics, 2013) were conducted to determine significant differences between the datasets (Table 1).

\section{Unpublished research}

Taxonomic researches conducted at the universities and research institutions are not always translated into research papers, but remain as unpublished theses. To understand the extent of such research, a questionnaire survey was carried out with the academics of four major public universities of Bangladesh teaching and conducting research on angiosperm taxonomy since long. These are University of Dhaka, University of Chittagong, University of Rajshahi and Jahangirnagar University. Number of Master's, MPhil and PhD theses submitted to these universities during 2003-2012, along with the number of academic taxonomists, were collected through this survey.

\section{Results \\ Overall trends}

Over the last 40 years plant taxonomic studies in Bangladesh has shown significant increase (Fig. 1). A steep, almost 10-fold rise was seen between 1990 and 2001, accounted for the publication of BJPT since 1994. If we compare 1994-2002 and 2003-2012 (Table 1), the total score increased by $13.4 \%$ in the latter period. Nonetheless, since the peak of 2001, a slow decline was seen (Fig. 1), especially since the middle of the last decade (Fig. 2). If we consider all Bangladeshi and foreign taxonomy papers of the studied journals, we however find a $54 \%$ rise over the last decade (Fig. 2). Over the last decade, proportion of foreign papers increased significantly in the studied journals. During 2003-2007, foreign papers accounted for $17 \%$ score, which rose to $47 \%$ during $2008-2012$.

\section{Inventory and integrated studies}

Annual average score of inventory studies by Bangladeshi authors has decreased by $15 \%$ over the last decade, but not significantly at $p<0.05$ level (Table 1, Fig. 2). For 2003-2012, "new records' (annual average score 19.3) was the most prominent inventory studies (Fig. 3a). More than $46 \%$ of the new record scores came from algal papers and $38 \%$ from angiosperm papers. Revisionary work was the most dominant type of inventory study during 1994-2002 (annual average score 9.8). This dominance lessened substantially during 2003-2012 (annual average score 7.4). The Bangladesh National Herbarium, however, published 7 fascicles of Flora of Bangladesh during 2003-2012, while the number was 4 in 1994-2002.

\section{Taxonomy in research institutes}

In four surveyed universities, successful angiospermic research conducted annually by Master's students doubled over 2003-2012 (Fig. 4). Research for MPhil degree has always been very low. $\mathrm{PhD}$, on the contrary, showed increasing trend in recent years. Interestingly, the total 
number of angiospermic taxonomists in these universities remained around 9 over the last 10 years (Fig. 4). A number of experienced taxonomists retired and/or died over this period replaced by young ones.

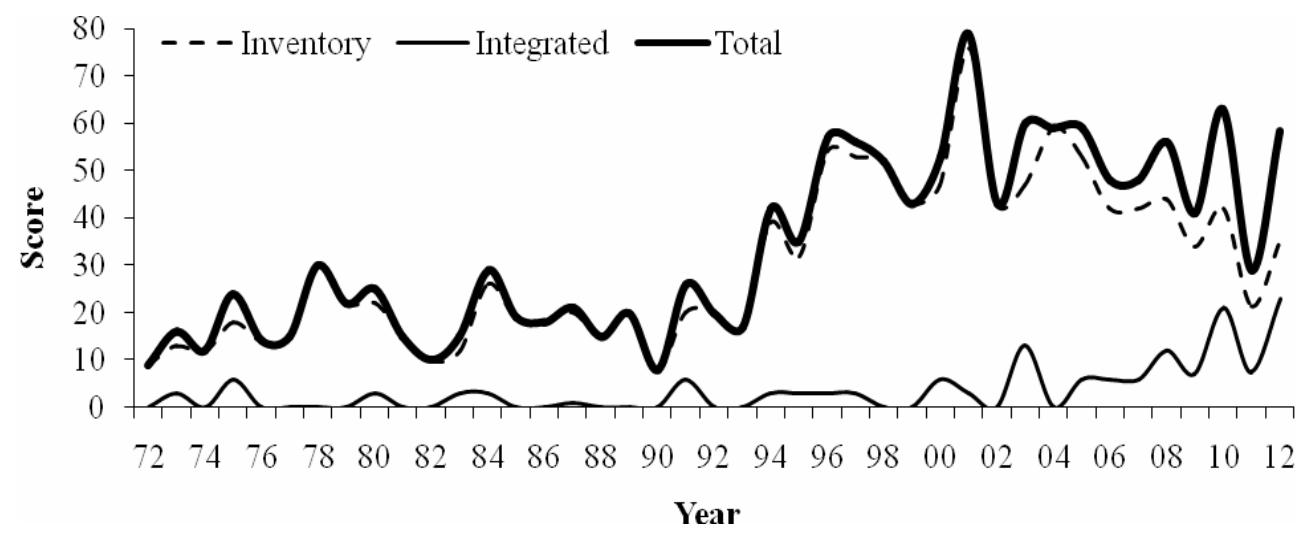

Fig. 1. Annual scores of inventory, integrated and total Bangladeshi taxonomic studies published in three journals and Flora of Bangladesh (1972-2012). Bangladesh Journal of Botany was first published in 1972, Journal of the Asiatic Society of Bangladesh, Science in 1975, and Bangladesh Journal of Plant Taxonomy in 1994.

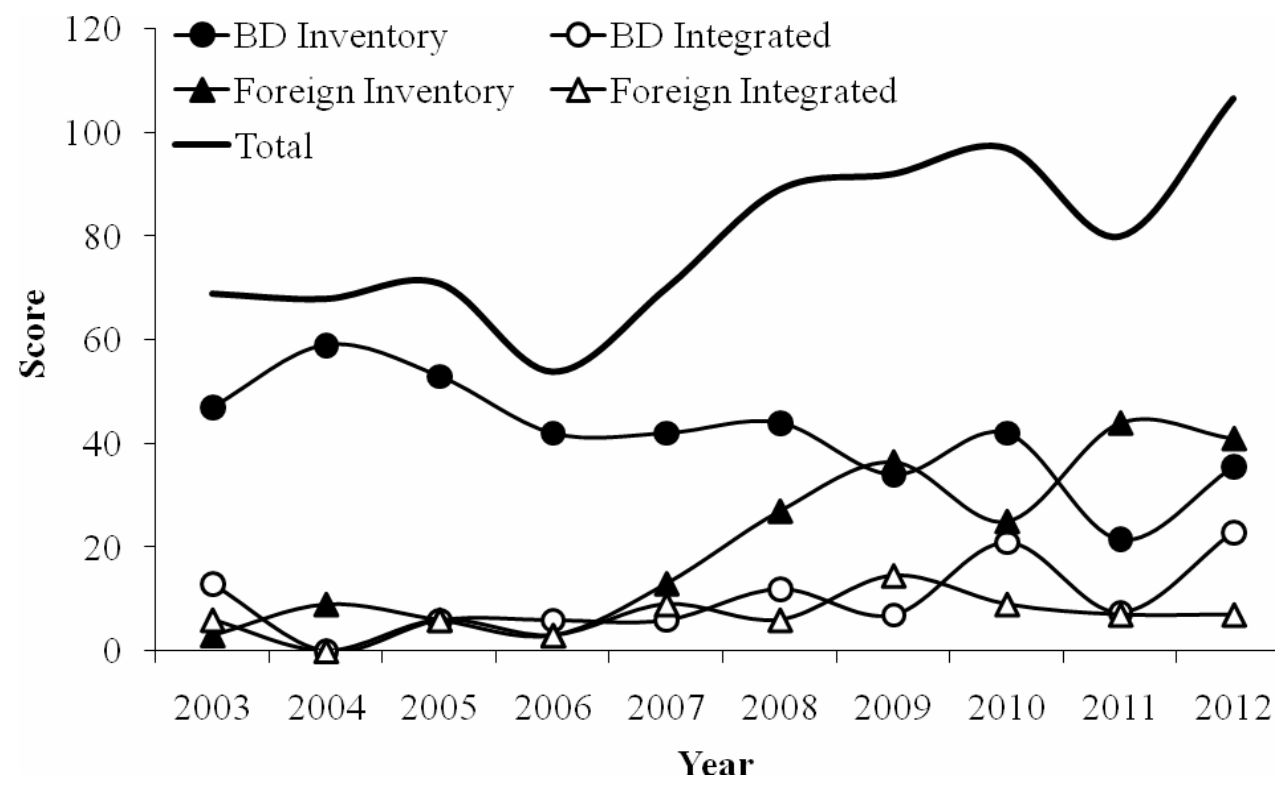

Fig. 2. Annual scores of Bangladeshi (BD), foreign and total inventory and integrated studies published in three journals and Flora of Bangladesh (2003-2012). Definitions and comments on different study types are given in the methodology section. Bangladesh Journal of Plant Taxonomy was first indexed by the ISI in 2007, became available on-line in 2008, and received first impact factor in 2010. 

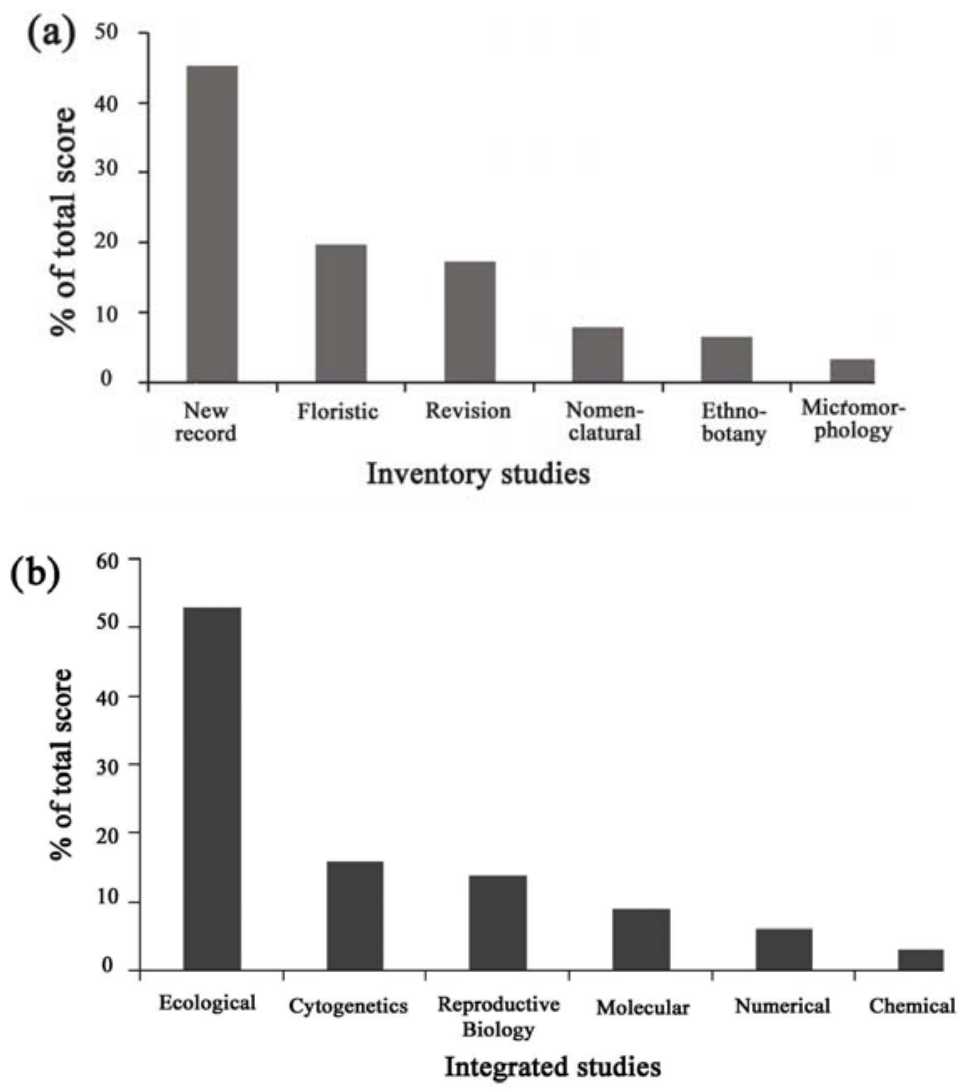

Fig. 3. Proportions of different types of a) inventory studies and b) integrated studies by Bangladeshi authors as the percentage of respective total scores (2003-2012). Definitions and comments on different study types are given in the methodology section.

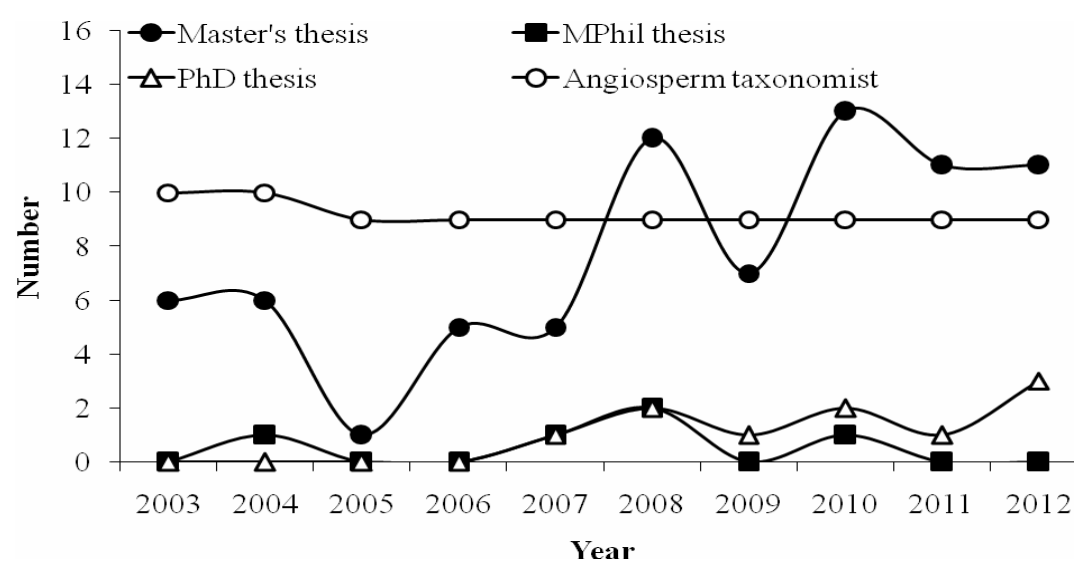

Fig. 4. Annual total Master's, MPhil and PhD theses on angiosperm taxonomy submitted in University of Dhaka, University of Chittagong, University of Rajshahi and Jahangirnagar University, and number of academic angiospermic taxonomists worked in these institutions (2003-2012). 


\section{Discussion}

Trends so far

Irfanullah (2003) described Bangladesh as a good example of strong taxonomic studies despite global decline. The present study, however, revealed some important trends in plant taxonomic research in Bangladesh over the last 10 years. If we start with the number of academic taxonomists, there is no net change in the number of active angiospermic taxonomist in the studied universities, rather slight decrease. This trend could also be seen in other research institutes. For example, Bangladesh National Herbarium had 9 taxonomists in 2003, but 5 in 2012. Despite the retirement of several experienced, senior taxonomists from the universities, the increased proportion of young academic taxonomists may be one of the reasons why Master's theses number increased significantly over the past decade despite having same number of taxonomists. This may have coupled with recent changes in university curricula and examination system encouraging or compelling more students to do research in taxonomy.

The above positive trend contradicts with the recent decline in plant taxonomy papers authored by Bangladeshi taxonomists. This decline, however, may not represent the full picture for a couple of reasons. It could be assumed that the rate of manuscript produced by the researchers has increased significantly matching the recent Master's thesis production rate. But, Bangladeshi journals usually do not entertain more than one paper by the same author(s) in one issue of a volume because of page limitations. Moreover, young taxonomists now have good exposure and are aware of many journals in Bangladesh and abroad accepting taxonomy-related papers. It is, therefore, very likely that young researchers are publishing more papers simultaneously in other Bangladeshi journals (not considered in the present study) and foreign journals. These assumptions, however, could not be confirmed by the present study, and demands further investigation to understand the research communication dynamics.

The third significant trend is related to the indexing of BJPT which has shot up its impact factor (5-year average is 0.427 ) and has attracted many foreign authors. This emphasizes the importance of taxonomy journals to be indexed with the ISI (Wägele et al., 2011). Increased proportion of foreign papers in Bangladeshi journals (BJPT and BJB), however, reduced the proportion of Bangladeshi papers. This could also explain the decline of overall Bangladeshi papers in the last few years. I am terming this as 'reputational backlash' since increased reputation of Bangladesh-origin journals causing negative impacts on Bangladeshi research publication. Increasing the number of issues or pages per volume could be a simple way out. Nevertheless, since all Bangladeshi journals engage volunteer editors and almost all depends upon external donations or strict budget, such drastic expansion is not always possible. Going for totally on-line journal may reduce printing cost. ICBN rules updated in 2011 will allow that as well (Knapp et al., 2011). But, as mentioned above, the manuscript submission rate of Bangladeshi authors is very low (only $12.3 \%$ of total submission for BJPT in 2012). This might indicate possible challenges Bangladeshi taxonomists are facing in producing quality, publishable manuscripts.

The fourth major trend recognized by this study is the dominance of plant groups in taxonomic research. Although angiosperm remains the dominant plant group, algal studies increased by $42 \%$ in the last decade compared with the previous decade. There are two possible reasons for this. First, while angiosperm taxonomists are mostly full-time taxonomists involved mostly in conventional taxonomy, algal taxonomists are also involved in ecological studies (integrated studies) along with classical taxonomy. Second, the rate of discovering algal taxa as new records for Bangladesh or new to science is much more than that of angiosperms. For example, a four-season sampling of a couple of water bodies in the tea gardens of Srimangal, Moulvi Bazar district revealed 421 algal taxa (Islam and Irfanullah, 2006) of which 130 were new 
records and 3 were new to science (present author's count). There is, however, a historical reason behind these different discovering rates. Exploration of angiosperm started in this part of the world more than two centuries back (Khan, 1991), but that of algae got momentum around the middle of $20^{\text {th }}$ century (Islam, 1991). Therefore, the chance of getting a new angiospermic record is much less than algae.

It was assumed that preparation of the voluminous Encyclopedia of Flora and Fauna of Bangladesh could have slowed down the original plant taxonomic research in Bangladesh. No such clear connection was found in the present study. Instead, since only published papers were considered in the Encyclopedia, it was important for the taxonomists to publish their unpublished work. A quick search of the bibliography of the Encyclopedia showed that plant taxonomists of some branches successfully did that.

It is a fact that the rise of taxonomic study cannot continue indefinitely as journals have annual page restrictions. Moreover, length of a paper, number of paper per issue, and ratio of full paper and short communication are some other factors which can influence studies like the present one based upon journal metadata. But changes in proportions - inventory studies versus integrated studies, Bangladeshi papers versus foreign papers, among plant groups, among types of study may happen over the years and can be used to identify major trends. This approach was taken in the present study.

\section{The future}

Prof. Md. Salar Khan estimated the total angiosperm taxa of Bangladesh would be around 5,000 under 186 families (Khan and Alam, 1977). The Encyclopedia (2007-2009) registered 3,611 taxa of angiosperms from Bangladesh territory (Irfanullah, 2011a). In a paper presented on 30 September 2013, Prof. Md. Abul Hassan proposed that if we consider the current rate of discovering new records for Bangladesh (64 species after publishing last volume of the Encyclopedia in June 2009) and of describing of species from Bangladesh that are new to science (8 species, after June 2009), can explore all the unexplored areas of Bangladesh, can examine all specimens from Bangladesh territory stored in the global herbaria, and can identify all unidentified specimens of Bangladeshi herbaria, the total number of angiosperm species may reach close to 5,000 (Hassan, 2013). But the recent pace of addition of angiosperm taxa to the Bangladesh flora suggests another 50-60 years would be needed to reach the magic number 5,000 envisaged by Prof. Khan 36 years back. In case of other plant groups, the Encyclopedia recorded 3,002 algal taxa (including cyanobacteria) under 424 genera and 127 families. As mentioned above, full inventory of algae is far from over. Therefore, despite the recent significant growth in integrated taxonomic studies in Bangladesh, inventory studies are expected to continue dominating Bangladesh's plant taxonomy in the coming years.

If we go back to the opening topic of this article - the number of taxonomists - we find three arguments: the number is increasing (Costello et al., 2013a), it is decreasing (Hopkins and Freckleton, 2006) or it is not enough (Bacher, 2012; Sluys, 2013). The present study places Bangladesh in the third trend. Nevertheless, these proposed trends depend upon different factors, for example, the taxonomic groups we are considering (Irfanullah, 2006; Samyn and de Clerck, 2012; Costello et al., 2013b; De Clerck et al., 2013) and their geographical occurrence (Joppa et al., 2011b). Equally important is the location of the taxonomists. For example, Asia and South America are showing relatively greater increase in taxonomic activities in recent decades (Wishart and Davies, 1998; Irfanullah, 2003; Tancoigne et al., 2011; Costello et al., 2013a). Nonetheless, a few simple recent statistics highlight some interesting trends. The reduced number of species described per taxonomist over the last three decades (Tancoigne and Dubois, 2013) may indicate several taxonomists together describing a single species - the "et al. effect" (Costello et al., 
2013b). Increase in interdisciplinary publications (Irfanullah, 2006; Tancoigne and Dubois, 2013) may also indicate that those currently involved in taxonomic work may no longer be full-time taxonomists. Therefore, part-timers are probably playing a major role in recent increase in taxonomic research (Joppa et al., 2011a; Samyn and de Clerck, 2012; Costello et al., 2013b). Recent increase in algal research shown in the present study corresponds to this trend. All these indicate that taxonomy is going through a new time.

But, how do we define 'taxonomists' in this new era? This may sound a strange question to ask, but probably not a wrong one. Many recent studies on trends in taxonomy define taxonomists as individuals who describe new species (e.g. Joppa et al., 2011a; Costello et al., 2013a). But surely, "describing a species" is not same as "knowing a species" (Tancoigne et al., 2011). Furthermore, this species-describing image of taxonomy often overshadows taxonomy's conceptual, analytical, and hypothesis-testing roles in wider biological sciences (de Carvalho et al., 2013; Sluys, 2013). Consequently, undermines the capacity of taxonomists as well. In the design of the present study, I have acknowledged this unique but broader aptitude of plant taxonomists. Therefore, the trends identified by the present analyses complement the bigger pictures portrayed by large metadata.

Investments to develop, to guide and to encourage new taxonomists, both professional and amateur, have been considered one of the major ways out, either for completing the global biodiversity inventory or for saving the taxonomist profession (Ebach et al., 2011; Pearson et al., 2011; Sluys, 2013). In addition to these and other propositions listed in the Introduction of this paper, I further emphasize the need for change the way taxonomists perceive their role. Let me explain this further by taking post-2015 discourse as an example.

On 30 May 2013, a High-level Panel of Eminent Persons proposed 12 universal goals and 54 national targets, on behalf of the United Nations, to guide global sustainable development after the MDGs expire in 2015 (United Nations, 2013). Although eradicating extreme poverty is the main target, gender, education, health, food security, water \& sanitation, energy, livelihoods, natural resource management, governance, peace and finance also made this list. The plant taxonomists can directly link their work to the "Universal Goal 9: Manage Natural Resource Assets Sustainably", specifically to two national targets: "Safeguard ecosystems, species and genetic diversity" and "Reduce deforestation by $\mathrm{x} \%$ and increase reforestation by $\mathrm{y} \%$ ". But to contribute effectively to these, plant taxonomists must broaden the way they currently see their discipline. With changed perspective and mindset, plant taxonomists can be able to actively contribute to these global and national agendas. The need for such change in the mindset of biologists of developing countries has repeatedly been talked about in recent years (Irfanullah 2011b, 2012). Plant taxonomists need to come out of their comfort zone, be innovative in conducting their research, focus more on integrating with other branches of biology, and link their work with real life problems. They also need to be the advocates of their own work, proactively communicating their research to other academics, general mass, decision-makers and policy-makers using different media. Taxonomists must capitalize on the positive momentum recently created at national (e.g. publication of Encyclopedia of Flora and Fauna of Bangladesh and Bangladesh Journal of Plant Taxonomy) and global levels (Costello et al., 2013a). Their changed ways of thinking and of action can place 'taxonomy' as a compelling issue in the on-going sustainable development discourse.

\section{Acknowledgements}

The author thanks Prof. M. Atiqur Rahman of University of Chittagong, Prof. Saleh Ahammad Khan of Jahangirnagar University, Prof. Md. Oliur Rahman of University of Dhaka, and Dr. A.H.M. Mahbubur Rahman of University of Rajshahi for providing with information on 
taxonomic research of their respective universities. Thanks are also due to Prof. Md. Oliur Rahman, Executive Editor of Bangladesh Journal of Plant Taxonomy (BJPT) for providing information on BJPT and commenting on an earlier version of this manuscript. The author was the Executive Editor (2006-2009) and is a member of the Editorial Board (since 2010) of BJPT. Through this paper, the author pays his respect to Prof. Md. Salar Khan (1924-2002) and National Prof. A.K.M. Nurul Islam (1928-2006), two legendary figures of plant taxonomic research in Bangladesh.

\section{References}

Ahmed, Z.U., Begum, Z.N.T., Hassan, M.A., Khondker, M., Kabir, S.M.H., Ahmad, M., Ahmed, A.T.A., Rahman, A.K.A. and Haque, E.U. (Eds) 2007. Encyclopedia of Flora and Fauna of Bangladesh, Vol. 3. Algae: Chlorophyta (Aphanochaetaceae- Zygnemataceae). Asiatic Society of Bangladesh, Dhaka, pp. 1812.

Ahmed, Z.U., Begum, Z.N.T., Hassan, M.A., Khondker, M., Kabir, S.M.H., Ahmad, M., Ahmed, A.T.A., Rahman, A.K.A. and Haque, E.U. (Eds) 2008a. Encyclopedia of Flora and Fauna of Bangladesh, Vol. 6. Angiosperms: Dicotyledons (Acanthaceae - Asteraceae). Asiatic Society of Bangladesh, Dhaka, pp. 1408.

Ahmed, Z.U., Hassan, M.A., Begum, Z.N.T., Khondker, M., Kabir, S.M.H., Ahmad, M., Ahmed, A.T.A., Rahman, A.K.A. and Haque, E.U. (Eds) 2008b. Encyclopedia of Flora and Fauna of Bangladesh, Vol. 12. Angiosperms: Monocotyledons (Orchidaceae - Zingiberaceae). Asiatic Society of Bangladesh, Dhaka, pp. 1-552.

Ahmed, Z.U., Khondker, M., Begum, Z.N.T., Hassan, M.A., Kabir, S.M.H., Ahmad, M., Ahmed, A.T.A., and Rahman, A.K.A. (Eds) 2009a. Encyclopedia of Flora and Fauna of Bangladesh, Vol. 4. Algae: Charophyta-Rhodophyta (Achnanthaceae- Vaucheriaceae). Asiatic Society of Bangladesh, Dhaka, pp. $1-543$.

Ahmed, Z.U., Hassan, M.A., Begum, Z.N.T., Khondker, M., Kabir, S.M.H., Ahmad, M., Ahmed, A.T.A., Rahman, A.K.A. and Haque, E.U. (Eds) 2009b. Encyclopedia of Flora and Fauna of Bangladesh, Vol. 7. Angiosperms: Dicotyledons (Balsaminaceae - Euphorbiaceae). Asiatic Society of Bangladesh, Dhaka, pp. 1-546.

Ahmed, Z.U., Hassan, M.A., Begum, Z.N.T., Khondker, M., Kabir, S.M.H., Ahmad, M., Ahmed, A.T.A., Rahman, A.K.A. and Haque, E.U. (Eds) 2009c. Encyclopedia of Flora and Fauna of Bangladesh, Vol. 8. Angiosperms: Dicotyledons (Fabaceae - Lythraceae). Asiatic Society of Bangladesh, Dhaka, pp. 1-478.

Ahmed, Z.U., Hassan, M.A., Begum, Z.N.T., Khondker, M., Kabir, S.M.H., Ahmad, M. and Ahmed, A.T.A. (Eds) 2009d. Encyclopedia of Flora and Fauna of Bangladesh, Vol. 9. Angiosperms: Dicotyledons (Magnoliaceae - Punicaceae). Asiatic Society of Bangladesh, Dhaka, pp. 1-488.

Ahmed, Z.U., Hassan, M.A., Begum, Z.N.T., Khondker, M., Kabir, S.M.H., Ahmad, M., and Ahmed, A.T.A. (Eds) 2009e. Encyclopedia of Flora and Fauna of Bangladesh, Vol. 10. Angiosperms: Dicotyledons (Ranunculaceae - Zygophyllaceae). Asiatic Society of Bangladesh, Dhaka, pp. 1-580.

Bacher, S. 2012. Still not enough taxonomists: reply to Joppa et al. Trends Ecol. Evol. 27: 65-66.

Boero, F. 2001. Light after dark: the partnership for enhancing expertise in taxonomy. Trends Ecol. Evol. 16: 266.

Bramley, J. 1994. Biodiversity in freshwater ecosystems: the need for an aquatic plant taxonomy course? Freshwater Forum 4: 216-218.

Costello, M.J., May, R.M. and Stork, N.E. 2013a. Can we name earth's species before they go extinct? Science 339: 413-416.

Costello, M.J., May, R.M. and Stork, N.E. 2013b. Response to comments on "Can we name earth's species before they go extinct?" Science 341: 237-d. 
de Carvalho, M.R., Ebach, M.C., Williams, D.M., Nihei, S.S., Rodrigues, M.T., Grant, T., Silveira, L.F., Zaher, H., Gill, A.C., Schelly, R.C., Sparks, J.S., Bockmann, F.A., Séret, B., Ho, H.-C., Grande, L., Rieppel, O., Dubois, A., Ohler, A., Faivovich, J., Assis, L.C.S., Wheeler, Q.D., Goldstein, P.Z., de Almeida, E.A.B., Valdecasas, A.G. and Nelson, G. 2013. Does counting species count as taxonomy? On misrepresenting systematics, yet again. Cladistics DOI: 10.1111/cla.12045

De Clerck, O., Guiry, M.D., Leliaert, F., Samyn, Y. and Verbruggen, H. 2013. Algal taxonomy: a road to nowhere? J. Phycology 49: 215-225.

Deans, A.R., Yoder, M.J. and Balhoff, J.P., 2011. Time to change how we describe biodiversity. Trends Ecol. Evol. 27: 78-84.

Disney, H. 1998. Rescue plan needed for taxonomy. Nature 394: 120.

Ebach, M.C., Valdecasas, A.G. and Wheeler, Q.D. 2011. Impediments to taxonomy and users of taxonomy: accessibility and impact evaluation. Cladistics 27: 550-557.

Figueiredo, E., Moore, G. and Smith, G.F. 2010. Latin diagnoses: An unnecessary impediment — A response to Jørgensen. Taxon 59: 1565-1566.

Godfray, H.C.J. 2002. Challenges for taxonomy. Nature 417: 17-19.

Hassan, M.A. 2013. Professor Md. Salar Khan (1924-2002) and his contribution to angiosperm taxonomy. Prof. Md. Salar Khan Memorial Lecture 2013, organized by Bangladesh Association of Plant Taxonomists (BAPT), Department of Botany, University of Dhaka, Dhaka (unpublished).

Hopkins, G.W. and Freckleton, R.P. 2006. Declines in the numbers of amateur and professional taxonomists: implications for conservation. Anim. Conserv. 5: 245-249.

Irfanullah, H.Md. 2003. Present trends of plant taxonomy in Bangladesh and its future. Bangladesh J. Plant Taxon. 10: 99-111.

Irfanullah, H.Md. 2006. Algal taxonomy in limnology: an example of the declining trend of taxonomic studies? Hydrobiologia 559: 1-9.

Irfanullah, H.Md. 2011a. Conserving threatened plants of Bangladesh: miles to go before we start? Bangladesh J. Plant Taxon. 18: 81-91.

Irfanullah, H.Md. 2011b. Can plant scientists be part of national efforts to respond to climate change? The publication of Fifth International Botanical Conference 2011, Bangladesh Botanical Society, Dhaka, Bangladesh, pp. 40-43.

Irfanullah, H.Md. 2012. How do biologists respond to low-intensity armed conflicts? The case of Bangladesh (1961-2011). International J. Environ. Studies 69: 654-667.

Islam, A.K.M. Nurul 1991. Phycology. In: Two Centuries of Plant Studies in Bangladesh and Adjacent Regions (Ed. Islam, A.K.M. Nurul), Asiatic Society of Bangladesh, Dhaka, 97-153.

Islam, A.K.M. Nurul and Irfanullah, H.Md. 2006. Hydrobiological studies within the tea gardens at Srimangal, Bangladesh. VI. Desmids (Xanthidium, Arthrodesmus, Staurodesmus and Staurastrum). Bangladesh J. Plant Taxon. 13: 111-129.

Jones, F.C. 2008. Taxonomic sufficiency: The influence of taxonomic resolution on freshwater bioassessments using benthic macroinvertebrates. Environ. Rev. 16: 45-69.

Joppa, L.N., Roberts, D.L. and Pimm, S.L. 2011a. The population ecology and social behavior of taxonomists. Trends Ecol. Evol. 26: 551-553.

Joppa, L.N., Roberts, D.L., Myers, N. and Pimm, S.L., 2011b. Biodiversity hotspots house most undiscovered plant species. Proc. Nat. Acad. Sci., USA 108: 13171-13176.

Khan, M.S. 1991. Angiosperms. In: Two Centuries of Plant Studies in Bangladesh and Adjacent Regions (Ed. Islam, A.K.M. Nurul), Asiatic Society of Bangladesh, Dhaka, 175-194.

Khan, M.S. and Alam, M.K. 1977. Commelinaceae. In: Khan, M.S. (Ed.), Flora of Bangladesh, Fascicle No. 4. Bangladesh National Herbarium, Bangladesh Agricultural Research Council, Dhaka.

Knapp, S., McNeill, J. and Turland, N.J. 2011. Changes to publication requirements made at the XVIII International Botanical Congress in Melbourne - what does e-publication mean for you? BMC Evol. Biol. 11: 250. DOI: 10.1186/1471-2148-11-250.

Knapp, S., Wilson, K. and Watson, M. 2006. Electronic publication. Taxon 55: 2-3. 
Lee, M.S.Y. 2000. A worrying systematic decline. Trends Ecol. Evol. 15: 346.

MacLeod, N., Benfield, M. and Culverhouse, P. 2010.Time to automate identification. Nature 467: 154-155.

Maddison, D.R., Guralnick, R., Hill, A., Reysenbach, A.-L. and McDade, L.A. 2012. Ramping up biodiversity discovery via online quantum contributions. Trends Ecol. Evol. 27: 72-77.

McDade, L.A., Maddison, D.R., Guralnick, R., Piwowar, H.A., Jameson, M.L., Helgen, K.M., Herendeen, P.S., Hill, A. and Vis, M.L. 2011. Biology needs a modern assessment system for professional productivity. BioScience 61: 619-625.

Pearson, D.L., Hamilton, A.L., and Erwin, T.L., 2011. Recovery plan for the endangered taxonomy profession. BioScience 61: 58-63.

Samyn, Y. and de Clerck, O. 2012. No name, no game. European J. Taxon. 10: 1-3.

Siddiqui, K.U., Islam, M.A., Ahmed, Z.U., Begum, Z.N.T., Hassan, M.A., Khondker, M., Rahman, M.M., Kabir, S.M.H., Ahmad, M., Ahmed, A.T.A., Rahman, A.K.A. and Haque, E.U. (Eds) 2007 a. Encyclopedia of Flora and Fauna of Bangladesh, Vol. 2. Cyanobacteria, Bacteria and Fungi. Asiatic Society of Bangladesh, Dhaka, pp. 1-415.

Siddiqui, K.U., Islam, M.A., Ahmed, Z.U., Begum, Z.N.T., Hassan, M.A., Khondker, M., Rahman, M.M., Kabir, S.M.H., Ahmad, M., Ahmed, A.T.A., Rahman, A.K.A. and Haque, E.U. (Eds) 2007b. Encyclopedia of Flora and Fauna of Bangladesh, Vol. 5. Bryophytes, Pteridophytes and Gymnosperms. Asiatic Society of Bangladesh, Dhaka, pp. 1-391.

Siddiqui, K.U., Islam, M.A., Ahmed, Z.U., Begum, Z.N.T., Hassan, M.A., Khondker, M., Rahman, M.M., Kabir, S.M.H., Ahmad, M., Ahmed, A.T.A., Rahman, A.K.A. and Haque, E.U. (Eds) 2007c. Encyclopedia of Flora and Fauna of Bangladesh, Vol. 11. Angiosperms: Monocotyledons (Agavaceae Najadaceae). Asiatic Society of Bangladesh, Dhaka, pp. 1-399.

Silvertown, J. 2010. Taxonomy: include social networking. Nature 467: 788.

Sluys, R. 2013. The unappreciated, fundamentally analytical nature of taxonomy and the implications for the inventory of biodiversity. Biodiversity and Conservation 22: 1095-1105.

Social Science Statistics, 2013. Mann-Whitney U-value Calculator. <http://socscistatistics.com/tests/ mannwhitney/> Retrieved on 13 October 2013.

Tancoigne, E. and Dubois, A. 2013. Taxonomy: no decline, but inertia. Cladistics 29: 567-570.

Tancoigne, E., Bole, C., Sigogneau, A. and Dubois, A. 2011. Insights from Zootaxa on potential trends in zoological taxonomy. Front. Zool. 8: 1-13.

United Nations, 2013. A New Global Partnership: Eradicate Poverty and Transform Economies through Sustainable Development. The Report of the High-Level Panel of Eminent Persons on the Post-2015 Development Agenda. United Nations, New York.

Valdecasas, A.G., Castroviejo, S. and Marcus, L.F. 2000. Reliance on the citation index undermines the study of biodiversity. Nature 403: 698.

Wägele, H., Klussmann-Kolb, A., Kuhlmann, M., Haszprunar, G., Lindberg, D., Koch, A. and Wägele, J.W. 2011. The taxonomist - an endangered race. A practical proposal for its survival. Front. Zool. 8: 25. DOI: $10.1186 / 1742-9994-8-25$

Werner, Y.L. 2006. The case of impact factor versus taxonomy: a proposal. J. Nat. Hist. 40: 1285-1286.

Wheeler, Q.D., Knapp, S., Stevenson, D.W., Stevenson, J., Blum, S.D., Boom, B.M., Borisy, G.G., Buizer, J.L., de Carvalho, M.R., Cibrian, A., Donoghue, M.J., Doyle, V., Gerson, E.M., Graham, C.H., Graves, P., Graves, S.J., Guralnick, R.P., Hamilton, A.L., Hanken, J., Law, W., Lipscomb, D.L., Lovejoy, T.E., Miller, H., Miller, J.S., Naeem, S., Novacek, M.J., Page, L.M., Platnick, N.I., Porter-Morgan, H., Raven, P.H., Solis, M.A., Valdecasas, A.G., van der Leeuw, S., Vasco, A., Vermeulen, N., Vogel, J., Walls, R.L., Wilson, E.O. and Woolley, J.B. 2012. Mapping the biosphere: exploring species to understand the origin, organization and sustainability of biodiversity. Syst. Biodivers. 10: 1-20.

Whishart, M.J. and Davies, B.R. 1998. The increasing divide between First and Third Worlds: Science, collaboration and conservation of Third World aquatic ecosystems. Freshwater Biology 39: 557-567.

(Manuscript received on 17 October 2013; revised on 23 November 2013) 